\title{
IDENTIFIKASI KETIDAKLENGKAPAN PENGISIAN DOKUMEN REKAM MEDIS RAWAT JALAN BERDASARKAN TEORI MOTIVASI EKSPEKTANSI
}

\author{
IDENTIFICATION OF THE FULFILMENT OUTPATIENT'S MEDICAL RECORDS INCOMPLETENESS BASED \\ ON EXPECTANCY THEORY MOTIVATION
}

\author{
Alvina Revitasari \\ Fakultas Kesehatan Masyarakat, Universitas Airlangga \\ E-mail: revitasari.alvina@gmail.com
}

\begin{abstract}
Completeness of medical record documents becomes important because it describe the practice of quality services. East Java Community Eye Hospital have problems with completeness of medical record documentation. Incompleteness medical record documentation of outpatient at East Java Community Eye Hospital was rated at 87, 67\%. The object of this study was to identification the incompleteness of medical record documentation of outpatient based on Victor Vroom expectancy theory motivation at East Java Community Eye Hospital. The present study conducts a cross-sectional, descriptive research during May 2016 through to use questionnaires and observation on medical record documentation of outpatient. The respondent of this study were personnel who were filling the outpatient medical record documentation. These people were 5 doctors, 5 refractions, and 6 nurses. The result of the study showed that Filling of the medical record documentation at East Java Community Eye Hospital was low. Motivation has driving factor to the incompleteness of outpatient medical record documentation at East Java Community Eye Hospital. Suggestions given to monitoring the performance to complete the medical record documentation of outpatient.
\end{abstract}

Keywords: hospital, incompleteness, medical record, motivation, outpatient, victor vroom.

\section{PENDAHULUAN}

Rekam medis merupakan berkas yang berisi catatan dan dokumen tentang identitas pasien, pemerikasaan, pengobatan, tindakandanpelayanan lain yang telah diberikan kepada pasien. Penyelenggaraan rekam medis diawali dengan diterimanya pasien, dilanjutkan pencatatan data pasien selama medapatkan pelayanan di rumah sakit (Permenkes, 2008). Mutu pelayanan dapat dikatakan baik jika rekam medis pasien lengkap, cepat dan tepat dalam meberikan informasi bagi pelayanan kesehatan. Mutu rekam medis dapat meningkatkan pelayanan yang ada di rumah sakit. Rekam medis menjadi bukti yang paling kuat untuk melihat bagaimana pengobatan yang dilakukan oleh tenaga medis di rumah sakit dalam upaya penanganan dan pengobatan pasien. Rekam medis menjadi alat informasi mengenai penanganan yang dilakukan tenaga medis kepada pasien yang melakukan pengobatan di rumah sakit.

Kelengkapan pengisian dokumen rekam medis menjadi hal yang sangat penting karena jika ada isian yang tidak terisi akan berkurangnya informasi terkait pasien. Hal ini akan mengakibatkan kurang optimalnya pelayanan yang diberikan terhadap proses pengobatan dan penyembuhan. Berdasarkan Keputusan Menteri Kesehatan RI No.129/MENKES/SK/II/2008 tentang Standar Pelayanan Minimal (SPM) Rumah Sakit mengenai standard pelayanan rekam medis rumah sakit yaitu kelengkapan pengisian rekam medis maksimal 24 jam setelah selesai pelayanan memiliki standard yaitu $100 \%$.

Kelengkapan pengisian dokumen rekam medis rawat jalan di RSMM pada bulan AgustusDesember 2015 masih tergolong tidak lengkap. Ada beberapa isian yang tidak diisi oleh petugas yang 
bertanggungjawab dalam pengisian dokumen rekam medis. Data awal kelengkapan pengisian dokumen rekam medis bulan Agustus, angka ketidaklengkapan pengisian sebanyak $86,67 \%$, pada bulan September 93,33\%, bulan Oktober sebesar $73,33 \%$, bulan November $93,33 \%$, dan pada bulan Desember sebesar $86,67 \%$. Hal ini menggambarkan bahwa masih tinggi angka ketidak lengkapaan pengisian dokumen rekam medis rawat jalan di RSMM.

Angka ketidaklengkapan pengisian dokumen rekam medis yang relatif tinggi membuat pihak rumah sakit harus mengetahui penyebab dari permasalahan tersebut. Petugas yang bertanggungjawab dalam pengisian dokumen rekam medis belum dapat mencapai kinerja yang maksimal dalam pengisian dokumen rekam medis. Salah satu cara melihat kinerja petugas pengisian dokumen rekam medis ialah berdasarkan motivasi petugas yang bertanggungjawab dalam pengisian dokumen rekam medis. Masalah penelitian yang terjadi adalah masih tingginya angka ketidaklengkapan pengisian dokumen rekam medis rawat jalan di RSMM. Penelitian ini bertujuan untuk mengetahui motivasi petugas terhadap pengisian dokumen rekam medis rawat jalan di RSMM.

\section{PUSTAKA}

Motivasi merupakan sesuatu yang dimiliki oleh dalam diri individu untuk memberikan stimulus dan kekuatan dalam mengaktifkan dan menggerakkan perilaku menuju tujuan yang ingin dicapai. Motivasi mengacu pada dorongan yang positif dari dalam atau luar diri individu yang mendorong keinginan individu untuk mencapai tujuan (Daft, 2009). Teori motivasi proses menggambarkan masing-masing individu giat dalam melakukan suatu tindakan sesuai dengan harapan organisasi. Hal yang mampu menggerakkan motivasi tersebut ialah harapan yang diperoleh oleh individu tersebut. Terdapat bergabagi macam teori motivasi proses yaitu teori harapan milik Victor Vroom, teori keadilan milik S. Adam, dan teori pengukuhan milik B.F. Skinner.

Teori harapan milik Victor Vroom menyebutkan bahwa cara bertindak dari berbagai macam tingkah laku berdasarkan harapan terhadap keuntungan yang diperoleh dari kegiatan yang dilakukan oleh individu. Dasar teori harapan ialah memahami sasaran individu dan kaitan antara usaha dan kinerja, kinerja dan imbalan, dan imbalan dan kepuasaan kerja yang dilakukan. Teori harapan memberi kekuatan kepada individu untuk dapat bekerja dengan baik yang dipengaruhi oleh hubungan anatara apa ang diinginkan dan dibutuhkan individu. Individu akan termotivasi ketika upaya yang kuatakan menyebabkan kinerja yang baik dan kinerja yang baik akan menyebabkan imbalan yang diinginkan (De Simone, 2015).

Terdapat tiga komponen penting dalam teori harapan (Panjaitan, 2011), yaitu variabel Harapan (Expectancy)ialah sesuatu yang mewakili keyakinan individu dalam tingkatan tertentu diikuti dengan kinerja yang dilakukan. Skor harapan dari angka nol hingga satu. Harapan memiliki skor sebesar nol yang berarti tidak memiliki dampak diinginkan dalam kerja, dan jika skor satu maka memiliki dampak yang diinginkan dalam kerja. Angka yang yang didapat 
pada variabel harapan akan dikali dengan skor valensi tingkat pertama untuk menghasilkan skor motivasi pada individu.

Instrumentalis (Instrumentality) merupakan Keyakinan individu terhadap imbalan yang didapat atas pekrjaan yang telah dilakukan. Skor instrumentalis dari angka nol hingga satu. Instrumentalis memiliki skor nol yang bermakna individu memberikan keyakinan yang rendah, dan skor satu untuk keyakinan yang paling tinggi. Semakin tinggi keyakinan dalam memperoleh imbalan maka skornya akan meningkat Pertanyaan yang terkait variabel instrumentalis masing-masing akan dikalikan dengan variabel valensi untuk mendapatkan skor valensi tingkat pertama.

Valensi (Valence) merupakan pentingnya penilaian individu untuk memperoleh imbalan dari pekerjaan yang telah dilakukan. Skor valensi dari angka minus satu hingga satu. Valensi memiliki skor minus satu jika individu menghindar adanya valensi dan memiliki skor satu jika menginginkan valensi yang besar. Pertanyaan yang terkait variabel valensi masing-masing akan dikalikan dengan variabel instrumentalis untuk mendapatkan skor valensi tingkat pertama.

Kinerja ialah perilaku yang relevan dengan tujuan organsiasi. Kinerja merupakan kegiatan pegawai dalam organisasi memenuhi persyaratan sebuah pekerjaan (Heriyawan, 2014). Kinerja pada dasarnya apa yang dilakukan atau tidak dilakukan oleh pegawai. Terdapat empat faktor yang mempengaruhi kinerja pegawai . faktor tersebut ialah karakteristik lingkungan, karakteristik organisasi, karaktersitik pekerjaan, dan karaktersitik individu (Kopelman dalam Wawanda \& Wulandari, 2014). Kinerja petugas merupakan hasil karya petugas selama periode waktu tertentu dibandingkan dengan hal-hal yang dapat menyertainya, miasInya standar, target, dan kriteria yang ditentukdan dan disepakati oleh organisasi dan petugas yang menjalankannya. Penilaian kinerja ialah proses suatu organisasi mengevaluasi dan memberi penilaian terhadap kinerja petugas. Kegiatan ini memberi dampak perbaikan keputusan personalia dan memberikan dampak langsung kepada karyawan yang menjalankan pekerjaannya. Kinerja menjadi karya nyata dari seorang petugas terhadap pekerjaannya dan menjadi gambaran pencaaian hasil kerja yang dimiliki setiap petugas dalam mencapai tujuan organisasi (Aufan, 2014).

Rekam medis ialah berkas yang berisikan catatan dan dokumen tentang identitas pasien, pemeriksaan, pengobata, tindakan, dan pelayanan lain yang telah diberikan kepada pasien (Menkes RI, 2008). Tujuan penyelanggarakan rekam medis ialah terdokumentasinya informasi yang akurat tentang data pasien, pemeriksaan, pengobatan dan penanganan dan kesembuhan pasien. Rekam medis menkasi bukti infromasi yang berguna bagi tenaga kesehahan yang menangani pasien, rumah sakit, dan pasien itu sendiri (Pratiwi, 2008). Pihak rumah sakit yang berhak membuat dan mengisi rekam medis ialah dokter, dokter spesialis, dokter gigi, residen, dan tenaga paramedik. Mutu rekam medis akan menggambarkan mutu pelayanan kesehatan yang diselenggarakan. Syarat rekam medis yang bermutu ialah akurat agar mampu menggambarkan proses pemeriksaan, lengkap isian, dapat digunakan 
berbagai kepentingan, valid sesuai dengan pemeriksaan, tepat waktu yang ditentukan, dapat digunakan untuk pengambilan keputusan, dan seragam dan dibagukan untuk konsistensi (Sally, 2008).

\section{METODE}

Penelitian ini merupakan penelitian deskriptif cross sectional. Total populasi penelitian ialah petugas yang bertanggungjawab dalam pengisian dokumen rekam medis rawat jalan di RSMM yaitu 5 orang dokter, 5 orang refraksionis opstesien, dan 6 orang perawat. Penelitian dilaksanakan pada bulan April-Mei 2016 di Rumah Sakit Mata Masyarakat Jawa Timur. Penelitian ini menggunakan kuesioner yang dibagikan keseluruh responden penelitian sesuai dengan variabel motivasi sebagai teori yang digunakan. Variabelkinerja diteliti dengan cara observasi terhadap kelengkapan pengisian dokumen rekam medis pada bulan April 2016 yang diisi oleh dokter, refraksionis opstesien, dan perawat. Hasil kinerja akan diklasifikasikan menjadi 3 (tiga) jenis kinerja yaitu kinerja baik (0-33\%), kinerja cukup (34$67 \%)$, dan kinerja rendah (68-100\%).

Variabel harapan memiliki 1 (satu) pertanyaan yang memiliki skor antara 0 hingga 1 dan memiliki jawaban dengan skala Likert yang berisi 5 tingkat preferensi jawaban. Variabel instrumentalis memiliki 5 (lima) pertanyaan yang memiliki skor antara 0 hingga 1 dan memiliki jawaban dengan skala Likert. Variabel valensi memiliki 5 (lima) pertanyaan yang memiliki skor -1 hingga +1 dan memiliki jawaban dengan skala likert. Skor instrumentalis dan valensi dikali dengan masingmasing pertanyaan dan dijumlah dan menghasilkan skor valensi tingkat pertama (V1). Skor valensi tingkat pertama (V1) dikalikan dengan skor harapan dan akan menghasilkan skor motivasi. Skor motivasi keseluruhan petugas dirata-rata dan dikelompokkan menjadi 3 (tiga) jenis motivasi yaitu motivasi tinggi, sedang, dan rendah).

\section{HASIL DAN PEMBAHASAN}

Motivasi petugas yang diteliti untuk mengetahui ketidaklengkapan pengisian dokumen rekam medis rawat jalan di RSMM meliputi keyakinan terhadap upaya yang dilakukan akan berhasil (harapan), keyakinan terhadap imbalan yang didapat ketika pekerjaan yang dilakukan akan berhasil (instrumentalis), dan penilaian terhadap pentingnya imbalan yang diterima (valensi). Hasil skor ketiga variabel diatas akan diolah menjadi skor motivasi masing-masing petugas.

Keyakinan Terhadap Upaya yang dilakukan akan Berhasil (Harapan)

Harapan merupakan keyakinan petugas terhadap pengisian dokumen rekam medis yang dilakukan akan berhasil jika diisi dengan baik. Berikut adalah distribusi jawaban harapan dari petugas dokumen rekam medis. 
Tabel 1. Keyakinan terhadap Upayayang dilakukan akan berhasil oleh Petugas pengisian rekam medis di RSMM tahun 2016

\begin{tabular}{lcc}
\multicolumn{1}{c}{$\begin{array}{c}\text { Kategori } \\
\text { Harapan }\end{array}$} & Jumlah & Persentase (\%) \\
\hline Sangatyakinsekali & 2 & 12,5 \\
Sangatyakin & 9 & 56,25 \\
Yakin & 5 & 31,25 \\
Tidakyakin & 0 & 0 \\
Sangattidak & 0 & 0 \\
yakin & & 100 \\
\hline TOTAL & 16 & \\
\hline
\end{tabular}

Hasil dari pengisian kuesioner variabel harapan diketahui bahwa petugas sangat yakin dalam pengisian dokumen rekam medis akan berhasil yaitu sebesar $56,25 \%$. Hal ini menggambarkan bahwa petugas pengisian dokumen rekam medis yakin terhadap kemampuan mereka dan pekerjaan yang mereka jalani akan menghasilkan hasil yang optimal. Keyakinan petugas dalam pengisian dokumen rekam medis yang tinggi akan mendorong petugas untuk menjadikan pekerjaan yang dijalani sebagai sebuah tantangan dan meningkatkan semangat untuk melakukan hasil yang baik dalam pekerjaannya. Sehingga petugas memiliki keinginan dan dorongan untuk meningkatkan kemampuan dalam mengerjakan pekerjaan yang menjadi tanggungjawabnya (Suhartini dan Yusiyanti, 2007). Keyakinan petugas yang sangat tinggi terhadap keberhasilan pengisian dokumen rekam medis akan mendorong terbentuknya motivasi petugas untuk melakukan pengisian dokumen rekam medis rawat jalan yang baik dan lengkap.

\section{Keyakinan Terhadap Kinerja yang dilakukan} Menghasilkan Imbalan (Instrumentalis)

$$
\text { Instrumentalis merupakan keyakinan }
$$

petugas bahwa upaya yang dilakukan dalam melakukan pekerjaan akan mendapatkan imbalan yang sesuai dengan harapan dari petugas tersebut. Berikut adalah distribusi jawaban petugas pengisian dokumen rekam medis terkait insrumentalis.

Tabel 2. Keyakinan terhadap Kinerja yang dilakukan Menghasilkan Imbalan oleh Petugas pengisian rekam

\begin{tabular}{lcc}
\multicolumn{1}{c}{ Kedis di RSMM tahun 2016 } & & \\
\hline Sangatyakinsekali & Jumlah & Persentase (\%) \\
Sangatyakin & 0 & 0 \\
Yakin & 2 & 60 \\
Tidakyakin & 8 & 25 \\
Sangattidakyakin & 4 & 12,5 \\
\hline TOTAL & 2 & 100 \\
\hline
\end{tabular}

Berdasarkan hasil instrumentalis petugas pengisian dokumen rekam medis dapat diketahui bahwa petugas yang bertanggungjawab dalam pengisian dokumen rekam medis merasa yakin terhadap imbalan yang akan diberikan ketika mengisi isian dokumen rekam medis dengan baik yaitu sebesar60\%. Petugas merasa bahwa apa yang mereka kerjakan akan memberikan dampak terhadap tujuan organsiasi. Imbalan langsung maupun tidak langsung untuk diri petugas akan diberikan dari pihak rumah sakit jika melakukan pengisian dokumen rekam medis dengan baik. Hal 
ini dimungkinkan karena rumah sakit memberikan promosi kerja berdasarkan unsur usaha dan kerja keras yang dilakukan oleh petugas untuk mencapai kinerja yang optimal. Imbalan dalm bentuk finansial yaitu seperti adanya insentif yang diberikan untuk petugas akan memberikan nilai positif terhadap keyakinan petugas terhadap apa yang diinginkan (Suhartini dan Yusiyanti, 2007). Imbalan lain yang petugas merasa yakin akan mendapatkan hal tersebut dari pihak rumah sakit adalah perlindungan terhadap terjadinya suatu kasus. Petugas yakin kepada pihak rumah sakit akan memberikan penjaminan jika petugas yang bertugas dipengisian dokumen rekam medis mengalami kasus terkait pengisian dokuemen rekam medis pasien rawat jalan (Revitasari, 2016). Penghargaan dan pengakuan dari pimpinan rumah sakit menjadi imbalan non-finansial yang petugas pengisian dokumen rekam medis rawat jalan yakini akan diberikan ketika melakukan pekerjaan dengan baik. Instumentalis yang relatof tinggi atau keyakinan petugas terhadap imbalan yang akan diberikan sangat dipengaruhi oleh kepercayaan petugas pengisian dokumen rekam medis terhadap sistem manajemen rumah sakit terhadap imbalan yang akan diberikan. Kepercayaan ini yang mendorong petugas untuk yakin terhadap imbalan yang didapat dan membentuk motivasi dari dalam diri petugas untuk berusaha mengisi dokumen rekam medis dengan lengkap dan baik.

Penilaian Terhadap Imbalan yang diterima (Valensi)

Valensi ialah penilaian terhadap pentingnya suatu hal yang melekat pada imbalan yang didapat oleh petugas setelah melakukan pekerjaan dengan baik dan optimal. Berikut adalah distribusi jawaban petugas pengisian dokumen rekam medis terkait valensi.

Tabel 3. Penilaian terhadap Imbalan yang diterima oleh Petugas pengisian rekam medis di RSMM tahun 2016

\begin{tabular}{lcc}
\hline $\begin{array}{c}\text { Kategori } \\
\text { Valensi }\end{array}$ & Jumlah & Persentase (\%) \\
\hline Sangatpenting sekali & 0 & 0 \\
Sangatpenting & 1 & 6,25 \\
Penting & 10 & 62,5 \\
Tidakpenting & 3 & 17,75 \\
Sangattidakpenting & 2 & 12,5 \\
\hline TOTAL & 16 & 100 \\
\hline
\end{tabular}

Tabel diatas memberikan informasi bahwa bahwa petugas pengisian dokumen rekam medis rawat jalan penilaian terhadap imbalan yang diberikan ketika melakukan pekerjaan dengan baik dirasa penting persentase sebesar $62,5 \%$. Hal ini menggambarkan bahwa petugas merasakan bahwa imbalan yang didapat oleh petugas ketika melakukan pekerjaan dengan baik adalah suatu hal yang penting bagi diri petugas namun tidak cukup kuat unruk dapat meningkatkan motivai petugas dalam pengisian dokumen rekam medis rawat jalan. Imbalan yang dianggap penting dapat berupa imbalan finansial maupun nonfinansial. Adanya insentif, pengakuan dari atasan, pujian dari pimpinan, perlindungan terhadap suatu kasus, dan promosi kerja dianggap penting dalam diri petugas untuk mendorong 
melakukan pekerjaan yang lebih dan optimal (Suhartini dan Yusiyanti, 2007).Petugas memberi penilaian terhadap penting dan tidaknya suatu imbalan merupakan hal yang wajar. Hal ini didorong karena imbalan tersebut mampu menunjang pemenuhan kebutuhan hidup dan kebutuhan perlindungan dari pihak rumah sakit. Petugas pengisian dokumen rekam medis mengharapkan dan memberikan penilian terhadap imbalan yang akan diberikan ketika pekerjaan yang dilakuan berhasil. Masing-masing petugas memiliki porsi dan keterlibatan yang berbeda dalam pengisian dokumen rekam medis sesuai dengan profesi petugas. Porsi tugas yang diberikan juga mendorong petugas memberikan penilaian berbeda terhadap pentingnya imbalan yang akan diberikan dari pihak rumah sakit. Petugas yang memiliki porsi isian lebih banyak akan memiliki peniliain imbalan yang lebih tinggi daripada petugas yang memiliki porisi isian yang lebih sedikit.
Petugas yang memiliki porsi isian yang sedikit dan penilian terhadap pentingnya imbalan juga relatif rendah akan merasa pada level pekerjaan yang statis dan akan berpengaruh terhadap isian yang dilakukan untuk dokumen rekam medis rawat jalan. Imbalan yang diberikan juga belum sepenuhnya sesuai dengan apa yang diinginkan oleh petugas pengisian dokumen rekam medis baik yang memiliki porsi isian yang banyak maupun sedikit.

\section{Upaya Mencapai Kinerja (Valensi Tingkat Pertama / V1)}

Valensi tingkat pertama merupakan upaya yang dilakukan oleh petugas untuk mencapai kinerja yang optimal. Angka valensi tingkat pertama (V1) merupakan hasil perkalian dari skor valensi dan instrumentalis. Berikut adalah distribusi klasifikasi valensi tingkat pertama petugas pengisian dokumen rekam medis rawat jalan di RSMM.

Tabel 4. Upaya Mencapai Kinerja Petugas Pengisian Rekam Medis di RSMM tahun 2016

\begin{tabular}{lcc} 
Tabel 4. & Jumlah & Persentase (\%) \\
\hline KategoriValensi Tingkat Pertama & 4 & 25 \\
Tinggi & 0 & 0 \\
Sedang & 12 & 75 \\
Rendah & 16 & 100 \\
\hline TOTAL & & Pul \\
\hline
\end{tabular}

Berdasarkan tabel 4 dapat diketahui bahwa petugas memiliki usaha untuk mencapai kinerja yang masih relatif rendah dalam pengisian dokumen rekam medis yaitu sebesar $75 \%$. Variabel ini merupakan leburan dari persepsi yakin dan tidak yakinnya petugas terhadap imbalan (valensi) dan penting dan tidaknya imbalan (instrumentalis). Pada skor valensi, petugas cenderung memberikan jawaban yakin yang memiliki skor 0 . Hasil tersebut yang menyebabkan usaha dalam mencapai kinerja atau valensi tingkat pertama pada diri petugas menjadi rendah. Pentingnya imbalan yang diberikan ketika petugas dapat melakukan pekerjaan dengan baik memiliki angka yang tidak cukup kuat untuk membentuk motivasi petugas untuk dapat mengisi dokumen rekam medis dengan baik. Skor yang dimiliki masing-masing petugas memiliki hasil bahwa upaya yang dilakukan masih relatif rendah untuk mencapai kinerja yang optimal.

\section{Motivasi}


Motivasi merupakan suatu usaha yang dilakukan untuk mendorong diri petugas untuk mencapai kinerja yang baik. Motivsi dapat timbul dari dalam diri petugas maupun dari luar diri petugas untuk mendorong terciptanya hasil yang optimal bagi petugas. Hasil motivasi berdasarkan Victor Vroom ialah hasil perkalian dari skor valensi tingkat pertama (V1) dengan skor harapan yang dimiliki oleh petugas pengisian dokumen rekam medis rawat jalan. Berikut adalah distribusi jawaban petugas terkait motivasi dalam pengisian dokumen rekam medis.

Tabel 5. Motivasi Petugas pengisian rekam medis di RSMM tahun 2016

\section{KategoriMotivasi} Jumlah

Persentase (\%)

\begin{tabular}{lcc}
\hline Tinggi & 4 & 25 \\
Sedang & 0 & 0 \\
Rendah & 12 & 75 \\
\hline TOTAL & 16 & 100 \\
\hline
\end{tabular}

Hasil perhitungan terhadap skor motivasi diketahui bahwa motivasi petugas dalam pengisian dokumen rekam medis ialah rendah dengan persentase $75 \%$. Tingkat motivasi diperoleh berdasarkan hasil kuesioner mengenai motivasi yang dimiliki oleh petugas dalam pengisian dokumen rekam medis yang menjadi tanggung jawab masingmasing petugas. Hasil tersebut menunjukkan bahwa motivasi petugas masih tergolong rendah dan cukup sehingga akan berdampak pada kinerja yang dilakukan oleh petugas dalam pengisian dokumen rekam medis rawat jalan di RSMM. Petugas akan termotivasi untuk mengeluarkan usaha yang lebih tinggi ketika mereka yakin akan usaha yang dilakukan akan menghasilkan penilaian kinerja yang baik.Sedangkan pekerja yang memiliki motivasi yang rendah hanya melakukan usaha minimum untukmencapaisesuatu.Salah satu sumber yang memungkinkan motivasi petugas rendah adalah keyakinan para petugas bahwa usaha keras yang dilakukan, kemungkinan untuk mendapatkan penilaian kinerja sangat rendah (Wahyudi, 2016). Berdasarkan hasil penelitian tingkat motivasi petugas pada rawat jalan dalam pengisian dokumen rekam medis termasuk kategori rendah. Hal ini menggambarkan bahwa dalam pengisian dokumen rekam medis rawat jalan membutuhkan imbalan kerja yang diharapkan dan dianggap penting dan berguna oleh petugas sehingga berdampak pada meningkatknya motivasi dan menghasilkan kinerja yang baik. Petugas akan berupaya dengan baik apabila petugas tersebut yakin bahwa kinerjanya baik akan membuahkan penilaian yang baik pula dan kemudian akan diikuti adanya penghargaan organisasional seperti bonus, kenaikan imbalan, dan promosi kerja (Rangganda, 2013).

\section{Kinerja}

Kinerja yang dilakukan oleh petugas ialah mengisi dokumen rekam medis milik pasien rawat jalan. Masing-masing petugas yaitu dokter, refraksionis opstesien, dan perawat memiliki tanggungjawab dan tugas tersendiri sesuai dengan profesi dalam kolom isian yang harus diisi dalam dokumen rekam medis rawat jalan. Berikut adalah distrubusi kategori kinerja petugas rekam medis. 
Tabel 6. Kinerja pengisian rekam medis di RSMM tahun 2016

KategoriKinerja Jumlah

Persentase (\%)

\begin{tabular}{lcc}
\hline Baik & 5 & 31,25 \\
Cukup & 6 & 37,5 \\
Rendah & 5 & 31,25 \\
\hline TOTAL & 16 & 100 \\
\hline
\end{tabular}

Berdasarkan tabel diatas diketahui bahwa petugas dalam pengisian dokumen rekam medis memiliki kinerja yang cukup dalam pengisian dokumen rekam medis rawat jalan yaitu sebesar $37,5 \%$. Petugas memiliki kinerja yang tergolong kategori cukup karena masing-masing petugas memiliki tanggungjawab dan tugas masing-masing dalam pengisian. Porsi dan keterlibatan masing-masing petugas dalam pengisian dokumen rekam medis berbeda pada masing-masing tenaga kesehatan baik dokter, refraksionis opstesies, dan perawat sehingga mengakibatkan motivasi yang dialami oleh petugas menjadi tidak optimal dalam pengisian dokumen rekam medis. Beberapa petugas masih belum melakukan isian secara maksimal pada dokumen rekam medis yang mengakibatkan rekam medis pasien menjadi tidak lengkap dan akan berkurangnya nilai informasi yang dapat dipergunakan.

Analisis Ketidaklengkapan Pengisian Dokumen Rekam Medis Rawat Jalan

Berikut adalah hasil tabulasi silang antara motivasi petugas dengan hasil kinerja petugas.

Tabel 7. Tabulasi Silang Motivasi dengan Kinerja Petugas

\begin{tabular}{|c|c|c|c|c|}
\hline \multirow[b]{2}{*}{ Variabel } & \multicolumn{3}{|c|}{ Kinerja } & \multirow[b]{2}{*}{ Total } \\
\hline & Kurang & Cukup & & \\
\hline \multirow[t]{2}{*}{ Ren-dah } & 4 & 5 & 3 & 12 \\
\hline & $-33,30 \%$ & $-41,70 \%$ & $-25 \%$ & $-100 \%$ \\
\hline \multirow[t]{2}{*}{ Tinggi } & 1 & 1 & 2 & 4 \\
\hline & $-25 \%$ & $-25 \%$ & $-50 \%$ & $-100 \%$ \\
\hline & 5 & 6 & 5 & 16 \\
\hline Total & $-31,20 \%$ & $-37,50 \%$ & $-31,20 \%$ & $-100 \%$ \\
\hline
\end{tabular}

Berdasarkan tabel diatas dapat dengan apa yang mereka harapkan untuk dapatkan menunjukkan hasil bahwa petugas yang memiliki dari pihak rumah sakit. Petugas belum merasakan motivasi rendah memiliki kecenderungan mengisi bahwa apa yang diinginkan dalam usaha dokumen rekam medis yang kurang. Sedangkan petugas yang memiliki motivasi tinggi memiliki kecenderungan mengisi dokumen rekam medis yang baik. Petugas yang memiliki motivasi rendah dimungkinkan merasa apa yang dilakukan dalam pengisian dokumen rekam medis belum sebanding meningkatkan kinerja dalam pengisian dokumen rekam medis yaitu insentif, pujian dari pimpinan, adanya pengakuan, perlindungan terhadap suatu kasus, dan adanya promosi kerja belum didapat secara maksimal (Revitasari, 2016). Petugas pengisian dokumen rekam medis memiliki persepsi 
yang penting terhadap imbalan yang akan diberikan, persepsi tersebut tidak cukup kuat untuk meningkatkan motivasi petugas dalam pengisian dokumen rekam medis karena petugas masih ragu terhadap akan diberikannya imbalan tersebut jika pengisian yang dilakukan lengkap. Hal tersebut yang mendorong petugas belum mencapai motivasi yang baik dalam pengisian dokumen rekam medis dan mengakibatkan pengisian dokumen rekam medis yang kurang maksimal.Motivasi merupakan daya pendorong yang dapat memberikan petugas stimulus untuk menggerakkan kemampuan dalam bentuk keahlian atau keterampilan, tenaga, dan waktu untuk melakukan kegiatan yang menjadi tanggungjawabnya untuk mencapai tujuan organisasi. Agar memberikan hasil kinerja yang baik dan berkualitas seorang petugas pengisian dokumen rekam medis membutuhkan motivasi yang tinggi sehingga dapat meningkatkan kinerja petugas itu sendiri (Rangganda, 2013). Motivasi yang relative rendah pada dokter dan perawat dimungkinkan adanya factor lain yang tidak dapat diteliti dalam penelitian ini yaitu beban kerja petugas. Hal ini tampak pada dokter yang memiliki porsi isian yang tinggi dimungkinkan akan mengalami beban kerja yang berlebih sehingga akan berpengaruh terhadap isian rekam medis yang menjadi tanggungjawabnya. Pada penelitian terdahulu yang dilakukan oleh Trisianawati (2014) bahwa semakin rendah beban kerja pertugas mengakibatkan kinerja yang rendah pula. Hal ini yang dimungkinkan terjadi pada diri perawat karena perawat memiliki porsi isian dan keterlibatan yang relative kecil dalam pengisian dokumen rekam medis.

\section{SIMPULAN}

Motivasi petugas dalam pengisian dokumen rekam medis menjadi faktor yang menyebab ketidaklengkapan pengisian dokumen rekam medis rawat jalan di RSMM. Motivasi petugas yang kurang optimal ini didasari dari tingkat penilaian petugas terhadap pentingnya imbalan yang diberikan oleh pihak rumah sakit yang memiliki skor yang relatif rendah. Saran yang diberikan untuk pihak rumah sakit ialah melakukan pendekatan secara personal untuk mengkomunikasikan kemampuan rumah sakit terhadap pemberian imbalan dan melakukan pengawasan terhadap cara kerja dan hasil kinerja petugas pengisian dokumen rekam medis.

\section{DAFTAR PUSTAKA}

Aufan, Y. 2014. AnalsisPengaruhFaktorfaktorKarakteristikPekerjaanTerhadapKinerja Karyawan.Skripsi.UnversitasDiponegoro.

Daft, R. L. 2002. Manjemen.EdisiKelimaJilidSatu. Jakarta: Erlangga

De Simone, S. 2015. Expectancy Value Theory: Motivating Health Care Workers. American International Journal of Contemporary Reserch 5(2).pp.1-5

Heriyawan, M. S., danSetyowati, W. 2014. PengaruhKaraktesritikPekrjaandanPemberda yaanterhadapKinerjaPegawaidenganMediasi KomitmenOrganisas. Unisbank.

KeputusanMenteriKesehatanRepublik Indonesia Nomor129/MENKES/SK/II/2008. Jakarta: PresidenRepublik Indonesia.

Panjaitan, L. 2011. Penggunaaan Expectancy Theory dalamUpayaMengukurMotivasiKerjaKaryawa n di PT. CahayaKawi Ultra Polyntraco.Skripsi.Universitas Sumatera Utara.

PeraturanMenteriKesehatanRepublik Indonesia No.269/MENKES/PER/III/2008.Jakarta: PresidenRepublik Indonesia.

Pratiwi, Y. D., 2008. Analisis Kelengkapan Pengisian Resume Medis Pasien Rawat Inap RSIA Budi Kemuliaan Tahun 2008-2009 .Skripsi. Universitas Indonesia.

Rangganda, S. 2013. Pengaruh Gaya KepemimpinanTransformasionaldanMotivasiK erjaTerhadapKinerjaKaryawan.Tesis.Universit asDiponegoro.

Revitasari, A. 2016. Analisis Ketidaklengkapan Pengisian Dokumen Rekam Medis Rawat 
Jalan di Rumah Sakit Mata Masyarakat. Skripsi. Universitas Airlangga.

Sally, T., 2008. Analisis Ketidaklengkapan Pengisian Rekam Medis. Skripsi. Universitas Indonesia.

Suhartini., dan Yusiyanti, P. 2007. Pengaruh Motivasi Terhadap Produktivitas Kerja Karyawan PDAM Tirtamarta Yogyakarta (Pendekatan Teori Ekspektansi Victor Vroom). Jurnal Akuntansi \& Manajemen 18(3). pp.163-177

Trisianawati, DianiDwi.

2014 PengaruhMotivasiKerja, DisiplinKerja danBebanKerjaTerhadapKinerjaBidan di InstalasiRawatInapRuangObstetri RSUP Dr.
Kariadi Semarang. Skripsi.Universitas Dian Nuswantoro

Wahyudi, A. 2016.PengaruhPenilaianKinerja, DisiplinKerja,

danKomitmenOrganisasiTerhadapMotivasiKer jaKaryawanMataharidepartemen Store Tunjungan Plaza Surabaya. eJurnalManajemenKinerja, 2(1). pp. 37-45

Wawanda, D. W danWulandari R. D. 2014.PengaruhFaktorOrganisasidanPekerjaa nTerhadapKinerja

PONKESDES.JurnalAdministrasiKesehatan Indonesia, 